\title{
Toward a Vision of Movement Building in Adult Literacy Education
}

Ira Yankwitt, Literacy Assistance Center

Recently, a colleague of mine in his 20 s asked me when and why the discourse in the field of adult literacy education shifted from the language of "human rights" and "social justice" to the language of "human capital" and "workforce development." My response: the 1990s, neoliberalism, and the subsuming of federal funding for adult literacy education under the Workforce Investment Act (WIA) in 1998.

Neoliberalism has been the prevailing economic ideology in the United States for the past four decades; and, as Stephen Reder alludes to in his article, A Lifelong and Life-Wide Framework for Adult Literacy Education, the core tenet of neoliberalism is a faith in "free markets" to address all social, political, and economic ills. Neoliberal doctrine promotes free trade, deregulation of business and industry, decreased government spending, and greater privatization of services, and it regards individuals first and foremost as economic actors (i.e., workers and consumers). As Reder notes, neoliberalism narrows the purpose of adult literacy education to "increasing human capital." It justifies public investment in adult literacy education primarily for its potential to meet the needs of employers, expand the available workforce, and, ultimately, to grow the economy as a whole. Based on the norms of the market, neoliberalism strives to maximize efficiency and seeks measurable, near-term returns on investment; and, as codified in WIA (and later WIOA), it requires our field to measure the effectiveness of our programs principally by demonstrating students' success at increasing standardized test scores, attaining credentials, and entering into further training or employment.

As Reder points out, while the neoliberal understanding of the purpose and value of adult literacy education aligns with the employment and workforce goals of many of our students, it devalues other goals and motivations. It also fails to recognize that the economic outcomes it prioritizes sometimes only emerge over time. In response, Reder argues for a more expansive "lifelong" and "life-wide" framework that would measure impacts over longer periods of time and would be "structured around the literacy activities and purposes in individual adults' lives."

While I share Reder's critique of the current system and applaud his vision for a lifelong and life-wide framework, Reder's article raises several questions for me:

1. Is it possible for adult literacy programs to truly deliver on the promise of empowering students to achieve their life-wide goals without also participating in broader 
movements that seek to transform the oppressive social, political, and economic forces that circumscribe students' lives?

2. Given neoliberalism's focus on maximizing short-term return on public investment, and given the number of our students who enter at the lower levels of literacy and English language proficiency, will continuing to promote adult literacy education as an essential component of the workforce development system ever be a winning strategy for increasing funding for our field? Or is wedding ourselves to neoliberalism and attempting to justify the value of our programs by their workforce outcomes ultimately a losing proposition?

3. In many of our students' communities and/ or countries of origin, neoliberal policies have caused economic decline, a reduction in resources and services, and displacement. As community educators, how should we respond to this reality? Should we be tacitly accepting the neoliberal paradigm and our designated role within it? Or should we be actively critiquing and challenging neoliberalism itself?

In the 20 years since the implementation of WIA, federal funding for adult literacy education has remained largely stagnant, and actually decreased in inflation-adjusted dollars from FY2001-FY2019, despite the fact that the field serves fewer than $5 \%$ of those in need. Yet over these two decades, the field has moved away from identifying itself as part of the broader struggle for human rights and social justice. I contend that for those of us working with and in marginalized, exploited, and under-resourced communities, we must align our programs fully and explicitly with the grassroots movements for racial, social, and economic justice that are working to dismantle systemic inequities.
To me, this is both a moral imperative and, as I've come to believe through my experience in New York City, a smart political strategy. Indeed, I would argue that it is only by aligning ourselves with grassroots movements for justice that we can hope to also build the movement we need to elevate the importance of adult literacy education, increase funding, and advocate for a system that makes it possible for our students to truly realize their lifelong and life-wide goals.

I first entered the field of adult literacy education in 1993, after spending three and a half years teaching junior high school social studies in one of the lowest income, most under-resourced neighborhoods in NYC. Inspired by the work of Paulo Freire and other radical educators, I envisioned adult literacy classrooms and programs as spaces to give voice to students' knowledge and experiences and to provide them with the quality education that had been denied them by the inequitable school system I had observed firsthand; to critically interrogate the social, political, and economic discourse and institutions that impacted their lives; and to engage in collective action with others in their community to challenge and transform those systems.

I was working in a community-based organization near East Harlem where many of our students were women on public assistance who had endured inferior educations in the notoriously segregated NYC public schools and, as adults, were developing their own goals for the education that had been denied them. That fall, Rudy Giuliani was elected mayor and, almost immediately, began vilifying public assistance recipients. Capitalizing on the incendiary, racist myth of the indolent "welfare queen," the Giuliani administration began to embark on what would become the most ambitious "workfare" program in the country. Our students were under attack from our mayor 
and were at immediate risk of being pulled out of their classes and sent to work in city jobs that had historically been filled by unionized workerslosing their opportunity for an education in NYC for the second time in their lives-and getting paid less than minimum wage to perform often dangerous jobs in city parks and buildings. To many of us, workfare appeared to be a modernday form of public indentured servitude.

Throughout 1994 and 1995, our program-and the field as a whole-organized. We developed critical reading lessons around the history of welfare in the United States and myths and facts about welfare, deconstructing the rhetoric. We designed math lessons that compared and contrasted the portion of the federal budget that went to welfare to the portions that went to other expenditures, like the military. We had students engage in budgeting exercises that demonstrated the absurdity of the claim that one could live comfortably relying only on public assistance and food stamps. Our students wrote testimonials to present to policymakers and spoke out in public forums. We all marched in mass demonstrations. Perhaps most significantly, we formed alliances and worked in solidarity with longtime welfare rights and labor activists. The right to adult literacy education became part of the platform of welfare rights organizations, and the expansion of rights and benefits for all welfare recipients became part of the platform of adult literacy advocates.

We lost. Badly. Women on public assistance continued to be pulled out of our program until virtually none were left. In 1996, Giuliani's draconian workfare policy was enshrined into the federal Personal Responsibility and Work Opportunity Reconciliation Act (PRWORA) signed by Bill Clinton. Two years later, WIA was passed, reframing how our work would be understood and evaluated. Yet, for me, the experiences of those two years reinforced my sense of the power and purpose of adult literacy education and my sense of responsibility as a community worker and educator. It taught me that we need to look at our students holistically, not just as "adult literacy learners" but in the fullness of their social and personal identities and in the totality of their lives. It taught me to listen. It taught me how to ground curriculum and instruction in the real-life issues our students and their communities were confronting and connect learning in the classroom to action in the world. And it taught me about the power and potential of "intersectional" organizing-organizing that is rooted in an analysis of the multiple, interconnected forms of discrimination and oppression our students face.

WIA was enacted in 1998. After fighting against a "work first" policy for public assistance recipients, we were now being told to prioritize employment outcomes for even more of our students. Both the PRWORA and WIA emphasized reducing long-term costs to government, economic return on public investment, and meeting the needs of employers and markets rather than achieving educational equity and the full human potential of all. Yet, over time, we accepted our role and have continually tried to make the case that we are an essential and effective part of the human capital/workforce development system, worthy of increased funding. But in NYC, it's becoming increasingly clear that this approach isn't working.

New York State's current investment in adult literacy education is over two times its WIOA funding. Yet, like the federal funding itself, these funds have remained stagnant for the past 20 years, and NYS only serves about $3 \%$ of those in need. The argument that adult literacy education is critical to workforce development and economic growth has been met politely by policymakers and 
funders but has never been truly embraced. Just last year, NYS announced a \$175M investment in new workforce development funding. Yet not a single dollar is slated for an increase in adult literacy education. Here in NYC, there is significant private philanthropic support for workforce development, including a consortium of foundations that pool resources specifically to fund workforce development programs. Yet, recently, a senior staffer at a large foundation told me candidly that, while he recognizes that language and literacy skills and a high school diploma are necessary for economic security, his foundation was unlikely to substantially fund adult literacy education because they do not see evidence that as our students move up through the NRS levels, their income increases significantly. The reality is that with limited resources to invest in workforce development, there is skepticism that investing in adult literacy education will yield the immediate employment outcomes and short-term economic returns that funders seek, given the number of our students who enter at the lowest levels of literacy and the length of time they may need to improve their skills enough to be able to obtain living-wage jobs.

Despite this, adult literacy programs in NYC have seen a boost in their funding over the last four years, and the story of how we achieved this increase is instructive. For several years now, a number of prominent immigrant rights organizations in NYC have played a central role in our local adult literacy advocacy coalition and have framed the expansion of ESOL classes within broader immigrant access, immigrant integration, and immigrant justice agendas. In 2014, after the election of a new city council, we found a champion for whom this message resonated: the council's first Mexican American member, originally from El Paso, Texas, for whom the issue was both personal and fundamentally a matter of social justice, particularly in a "sanctuary city" that claimed to be committed to safety and opportunity for all immigrants. As a result of this framing and significant grassroots mobilizing and activism, we were able to secure a nearly fivefold increase in city funding for adult literacy services in 2016 (from $\$ 3.5 \mathrm{M}$ to $\$ 15.5 \mathrm{M}$ ) and have been able to maintain this funding for each of the subsequent years.

I've come to believe strongly in this model of forging alliances and working in solidarity with grassroots organizations, both to build power for our students and afford our field increasing opportunities to bring our perspectives to the broader visioning for social justice. Which organizations and movements we align with will be particular to the social identities of our students and the communities each of our programs serve, and the point of entry may either be through a specific, issue-based campaign or a broad-based, more comprehensive platform. One hypothetical example may be useful:

In cities throughout our country, there are any number of educational justice organizations fighting for fair and equitable funding for all schools and students, universal pre-K, an end to the segregation or re-segregation of public schools and districts, greater diversity and representation among faculties and administrations, culturally responsive curriculum and instruction, replacing harsh punitive discipline with restorative justice programs, and access to affordable higher education for all. Yet, in many cases, these organizations don't include adult literacy education as part of their agenda. Issues of educational equity are critical to our students, both because many are parents and because these issues are connected to other political and economic inequities impacting their lives. 
Aligning our programs with educational justice organizations and examining these issues in our classrooms can embolden students as agents of social change for their families and communities. This kind of collaboration can also create opportunities to call attention to the issue of adult literacy with educational justice organizations and to potentially integrate adult literacy education into their agendas.

In 2019, my organization, the Literacy Assistance Center, launched the Literacy \& Justice Initiative. The goals of the initiative are to engage and empower adult literacy students around issues that affect their communities; to strengthen grassroots organizing and situate adult literacy education within wider movements for social and economic justice; and to assemble a broader coalition to expand educational opportunities for the $2.2 \mathrm{M}$ adults in NYC without a high school diploma and/ or English language proficiency. The initiative currently has 45 community partners, including publicly funded adult literacy programs, workers' rights and immigrant rights organizations, advocacy groups, and grassroots communitybased organizations. We are now working with these partners to build a cross-sector collaborative network, share resources, engage in peer learning, cultivate grassroots leadership, and explore the potential of organizing for collective action.

I am inspired by and deeply committed to Reder's vision of a lifelong and life-wide framework for adult literacy education, one that moves beyond the neoliberal paradigm and embraces the diverse goals and full humanity of all of our students and their communities. And I believe that it is only by building alliances, working in solidarity, and engaging in intersectional movement building with grassroots racial, social, and economic justice organizations that the field of adult literacy can truly achieve this vision. 